\title{
DIRECT EVIDENCE OF RETENTION OF UNFER- TILIZED OVA IN THE OVIDUCT OF THE MARE
}

\author{
K. J. BETTERIDGE AND D. MITCHELL \\ Animal Pathology Division, Health of Animals Branch, \\ Agriculture Canada, Animal Diseases Research Institute, \\ P.O. Box 1400, Hull, Quebec, Canada
}

\section{(Received 10th Fanuary 1974)}

Van Niekerk \& Gerneke (1966) first showed that in mares several unfertilized ova can be found in the oviduct at any one time. This has been confirmed by Webel, Ellicott \& Dziuk (1970), Thompson (cited by Allen, 1970), Betteridge \& Mitchell (1972) and Steffenhagen, Pineda \& Ginther (1972) and has also been shown to occur in donkeys (Bielanski \& Zapletal, 1968). It seems highly probable that these ova originate from previous normal cyclic ovulations and persist in the oviduct for several months, but the evidence for this has so far been circumstantial in that persistence of individually marked ova has not been followed. During studies on the origin of accessory CL, we obtained direct evidence in two mares that individual ova were retained in the oviduct for periods of at least 24 days and 52 days. Three ova had been marked naturally by sperm penetration without fertilization at isolated matings and then, after these intervals, were recovered from the oviducts at slaughter.

Mare No. 1 was an aged, parous, $200-\mathrm{kg}$ pony which was subjected to laparotomy during anoestrus on 10th November, 1972. The oviducts were flushed (Betteridge \& Mitchell, 1972) to remove old ova and 3200 i.u. PMSG (Gestyl, Organon) was injected into the ovarian stroma in an attempt to induce superovulation. No response was detected by rectal palpation during the next 14 days. Twice daily subcutaneous injections of $500 \mu \mathrm{g}$ synthetic LH-releasing hormone (LH-RH, Ayerst) were given for 5 days beginning on 29th January 1973, together with daily intramuscular injections of 12,500 i.u. PMSG (Ayerst) on the last 2 days in a further attempt to induce superovulation. Again, no palpable response was detected. No critical examinations for oestrus were made thereafter until 5th April, when daily teasing with a stallion and thrice weekly inspection of the cervix per vaginam were commenced. Frequent rectal palpation of the ovaries was initiated each time signs of impending oestrus were seen and were continued until oestrus ended. Particular emphasis was placed on detection of ovulation by recording the consistency and dimensions of developing follicles. Five oestrous periods of 5, 3, 3,6, and 4 days were recorded, beginning at intervals of $19,19,18$ and 20 days, respectively. Only a single mating, on the 2nd day of the last oestrus, was permitted. At no time did the ovaries show any marked enlargement, maximum follicle size being estimated at $2 \mathrm{~cm}$. Ovulations were detected only twice (second oestrus, right side; third oestrus, left side). Following the fifth oestrus, the mare was consigned to a virus 
infection experiment and was slaughtered 30 days after mating. The autopsy findings are summarized in Table 1 and illustrated in Pl. 1, Figs 1 to 3.

Mare No. 2 was an aged, parous, 150-kg pony which mated and conceived on 19th May. A normal conceptus was removed surgically from the left uterine horn 34 days later and both oviducts were flushed. Teasing and palpation, as previously described, were instituted 14 days after surgery. An 8-day oestrus began 26 days after surgery and four matings were permitted on alternate days

Table 1. Post-mortem findings in two mares slaughtered 30 days (mare No. 1) and 58 days (mare No. 2) after insemination

\begin{tabular}{|c|c|c|c|c|c|}
\hline \multirow{2}{*}{$\begin{array}{l}\text { Mare } \\
\text { No. }\end{array}$} & \multirow{2}{*}{ Uterus } & \multicolumn{2}{|c|}{$C L$ in ovaries } & \multicolumn{2}{|c|}{ Old ova flushed from oviducts } \\
\hline & & Left & Right & Left & Right \\
\hline 1 & $\begin{array}{l}\text { 30-day conceptus at } \\
\text { base of left horn }\end{array}$ & $\begin{array}{l}\text { Two recent, } \\
\text { and at least } \\
\text { four old scars }\end{array}$ & $\begin{array}{l}\text { One recent, } \\
\text { and at least } \\
\text { three old scars }\end{array}$ & $\begin{array}{l}\text { Five ova, two } \\
\text { with sperm. in } \\
\text { zona } \\
\text { pellucida }\end{array}$ & $\begin{array}{l}\text { Six ova, none } \\
\text { with sperm. }\end{array}$ \\
\hline 2 & $\begin{array}{l}\text { Traces of endometrial } \\
\text { cups at base of left } \\
\text { horn }\end{array}$ & One recent & $\begin{array}{l}\text { Several old } \\
\text { scars }\end{array}$ & $\begin{array}{l}\text { One ovum } \\
\text { with sperm. } \\
\text { in zona } \\
\text { pellucida and } \\
\text { vitellus }\end{array}$ & $\begin{array}{l}\text { One ovum, } \\
\text { no sperm. }\end{array}$ \\
\hline
\end{tabular}

beginning on the 2nd day of oestrus. Although ripening follicles $(2.5$ to $4 \mathrm{~cm}$ in diameter) were palpated, no definite ovulations were detected. A left horn pregnancy was diagnosed 21, 28, 33 and 35 days after the last day of oestrus which was assumed to be the day of conception (Day 0 ). No conceptus was palpable on Day 37 and because of failure to detect ovulation and the loss of the pregnancy, regular examination and teasing were stopped and the mare was assigned to a virus infection experiment. Before infection, however, overt signs of oestrus were observed and during a single rectal examination on Day 43, a ripe follicle ( $3 \mathrm{~cm}$ diameter) ruptured on the left ovary. At autopsy on Day 58 (Table 1), the traces of endometrial cups in the base of the left horn were found close to prominent $5 / 0$ silk ligatures (from the hysterotomy) which may have contributed to the early fetal resorption. The recent CL in the left ovary had a tract to the ovulation fossa. The sperm-marked ovum is shown in Pl. 1, Figs 4 and 5.

\section{EXPLANATION OF PLATE 1}

Figs 1 and 2. Two old ova from the left oviduct of mare No. 1 with spermatozoa (arrows) in the zonae pellucidae (z.p.). About five spermatozoa were observed in the z.p. of one ovum (Fig. 1), and at least ten in the z.p. of the other (Fig. 2). Two additional old ova from this oviduct had no spermatozoa and the fifth was lost before critical examination. (Bright field, unstained, $\times 275$ ).

FIG. 3. Bisected ovaries from mare No. 1. Note the three GL of similar age with tracts to the ovulation fossae, the two in the left ovary sharing a common stigma.

Frgs 4 and 5. Old ovum from mare No. 2 with spermatozoa (arrows) in the z.p. At least five sperm heads without tails were seen within the degenerate vitellus, some exhibiting Brownian movement. (Bright field, unstained. Fig. 4, ×550; Fig. 5, × 275). 
PLATE 1

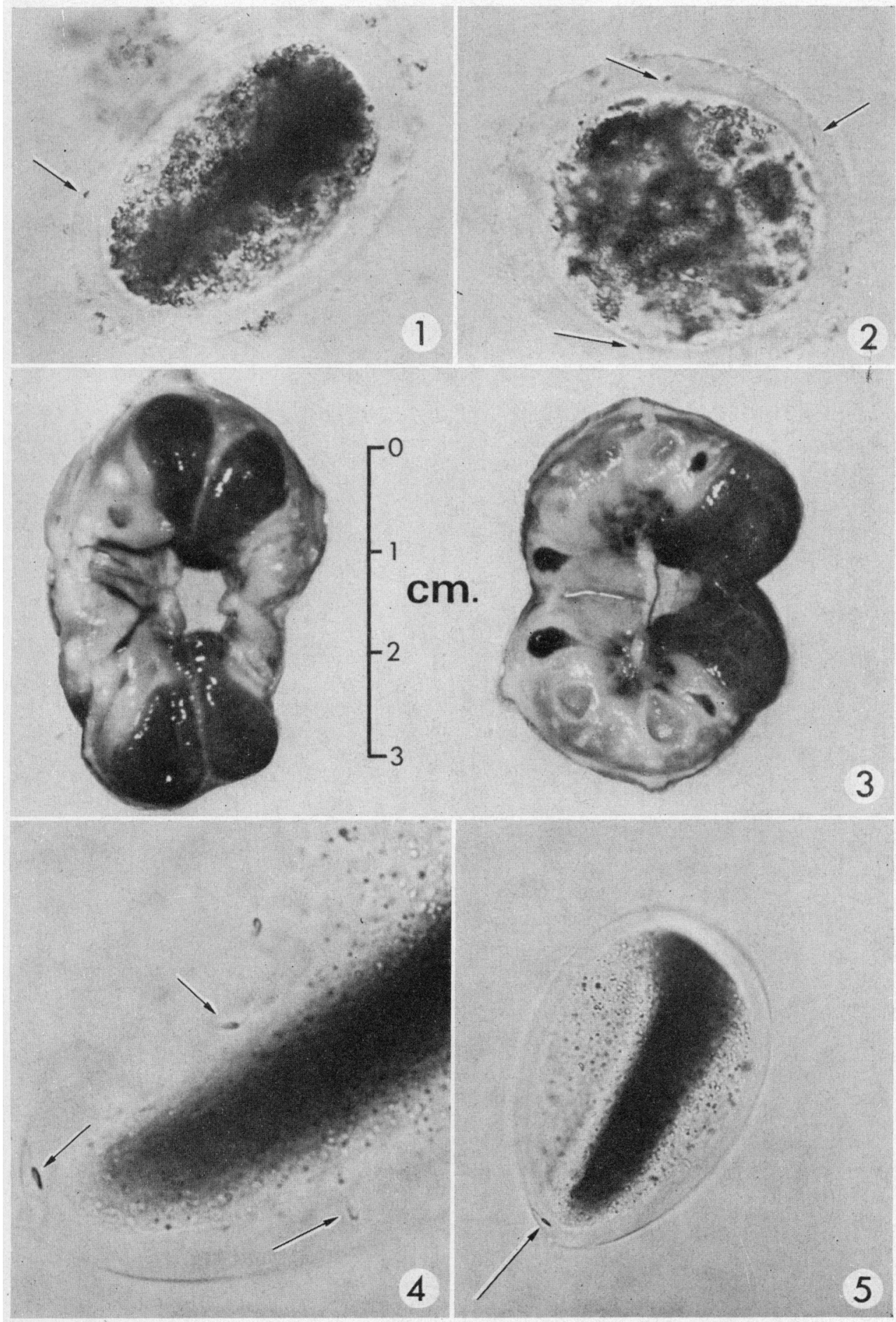

(Facing p. 146) 
In mare No. 1 , the only spermatozoa available to penetrate the two unfertilized ova came from the single mating 30 days before slaughter. Three possible sources for the ova require consideration: (1) they may have been shed at the same time as the egg that was fertilized; (2) they may have been old ova already persisting in the tube at the time of mating; (3) they may have resulted from accessory ovulations during the first 30 days of pregnancy. Source 1 seems the most plausible and is supported by the three associated CL (Pl. 1, Fig. 3) although triple ovulations occur in only about $1 \%$ of mares (Arthur, 1958; Osborne, 1966). Source 2 seems less likely since eight tubal ova in the same mare were devoid of spermatozoa. Source 3 could also account for the three CL but can be excluded because the maximum fertilizing life of equine spermatozoa is 6 days (Day, 1942; Burkhardt, 1949). This means that the sperm-bearing ova recovered at autopsy had been retained in the tube for at least 24 days. Five unpenetrated ova on the right side and two on the left could not be accounted for on the basis of rectally diagnosed ovulations. This had not been our experience previously (Betteridge \& Mitchell, 1972), but this mare had unusually small ovaries and even the ovulation(s) at the last oestrus before slaughter had not been detected. There were, therefore, ample opportunities for the ova to have originated either from undetected responses to two attempts to induce superovulation, from silent ovulations when rectal examinations were not being conducted (Stabenfeldt, Hughes \& Evans, 1972), or from additional multiple ovulations that had not been detected rectally during the four oestrous periods preceding the fertile one.

In mare No. 2, the only spermatozoa available to penetrate the unfertilized ovum came from matings 58 to 64 days before slaughter, indicating that the penetrated ovum had been retained in the oviduct for at least 52 days. Similar reasoning to that advanced for mare No. 1 suggests that the ovum had been ovulated at the time of the fertile ovulation, though neither had been detected rectally. Failure of more than one egg to be fertilized and passed into the uterus in each of these cases of probable multiple ovulation could be one explanation of why multiple pregnancy rates are much lower than multiple ovulation rates in mares (Arthur, 1958). The most recently ovulated ovum on the left side was not recovered, possibly as a result of a technically poor flush (the only oviduct that ruptured under pressure out of more than eighty). Again, the unpenetrated ovum on the right side could not be accounted for by a rectally diagnosed ovulation and must have been shed undetected, possibly during early accessory follicular activity before embryo resorption. It seems unlikely that it originated during the fertile oestrus because it should then also have been sperm-marked.

The existence of a means for retention of unfertilized ova in the oviducts of mares is thus confirmed by these new observations. The source of the retained ova is evidently normal cyclic ovulation and not rupture of polyovular follicles (van Niekerk \& Gerneke, 1966; Betteridge \& Mitchell, 1972). The mechanism of ovum retention remains obscure but the present observations suggest that the changes in the ovum which lead to differential transport of fertilized and unfertilized ova in the oviduct must be associated with fertilization proper and not just sperm penetration. Such changes are probably expressed as sur- 
face differences and must precede hatching from the zona pellucida because Oguri \& Tsutsumi (1972) have recovered unhatched blastocysts from the uterus 6 days after ovulation. Evidence that enzymes associated with steroid synthesis can be found in rat blastomeres as early as 4 days after fertilization (Dickmann \& Dey, 1973) suggest that analogous studies in horses might also help elucidate this enigma.

The technical assistance of Mrs J. Hierlihy, Mr J. Shackleton and, particularly, Mr R. Bériault, who first observed and photographed the spermatozoa in the ova, is gratefully acknowledged.

\section{REFERENGES}

ALLEN, W. R. (1970) Endocrinology of early pregnancy in the mare. Equine vet. 7. 2, 64.

ARTHUR, G. H. (1958) An analysis of the reproductive function of mares based on post-mortem examination. Vet. Rec. 70, 682.

Betteridge, K. J. \& Mrtchell, D. (1972) Retention of ova by the Fallopian tube in mares. F. Reprod. Fert. 31, 515.

Bielanski, W. \& Zapletal, Z. (1968) Ovulation in she-mules: a report of two cases. Proc. 6th Int. Congr. Anim. Reprod. \& A.I., Paris, 2, 1555.

Burkhard, J. (1949) Sperm survival in the genital tract of the mare. f. agric. Sci., Camb. 39, 201.

DAy, F. T. (1942) Survival of spermatozoa in the genital tract of the mare. F. agric. Sci., Camb. 32, 108.

Dickmann, Z. \& Dey, S. K. (1973) Two theories: the preimplantation embryo is a source of steroid hormones controlling (1) morula-blastocyst transformation, and (2) implantation. F. Reprod. Fert. 35, 615.

Oguri, N. \& Tsutsumi, Y. (1972) Non-surgical recovery of equine eggs, and an attempt at nonsurgical egg transfer in horses. F. Reprod. Fert. 31, 187.

OsBorne, V. E. (1966) An analysis of the pattern of ovulation as it occurs in the annual reproductive cycle of the mare in Australia. Aust. vet. F. 42, 149.

Stabenfeldt, G. H., Hughes, J. P. \& Evans, J. W. (1972) Ovarian activity during the estrous cycle of the mare. Endocrinology, 90, 1379.

Steffenhagen, W. P., Pineda, M. H. \& Ginther, O. J. (1972) Retention of unfertilized ova in uterine tubes of mares. Am. F. vet. Res. 33, 2391.

van Niekerk, G. H. \& Gerneke, W. H. (1966) Persistence and parthenogenetic cleavage of tubal ova in the mare. Onderstepoort 7. vet. Res. 33, 195.

Webel, S. K., Ellrcott, A. R. \& Dziuk, P. J. (1970) Control of ovulation and maturation of pony eggs. F. Anim. Sci. 31, 1036. 